\title{
AN EVALUATION OF A COMMUNICATION, FACILITATION AND PROJECT MANAGEMENT TOOL TO ENHANCE THE EFFECTIVENESS OF PROJECT EXECUTION
}

\author{
SCHALK VAN DER MERWE \\ schalk@connect.za.net \\ MARK BUSSIN \\ Department of Human Resource Management \\ University of Johannesburg
}

\begin{abstract}
Project managers are in desparate need of a tool to help them save time and bridge the gap between different interfaces which they use to document, present to the business and manage their projecs. Mindmanager x5 Pro appears to be a viable solution. But it is of utmost importance that before rolling out the solution in the business that the solution be evaluated in the specific environment. Mindmanager x 5 Pro makes certain claims that must be confirmed. Furthmore the software will be evaluated against best practices criteria in the field of change communication, facilitation and project management.
\end{abstract}

Key words

Project management tool, project execution, Mindmanagers x5 Pro

Today we are confronted with change that is exponential, that is, change heaped upon change (Eitington, 1997). The practices managers develop in order to work in a stable, predictable world, often no longer apply, and in fact are outmoded. Furthermore, the guideposts for management today and in future are far from clear. According to Buchanan \& Boddy (1992), two of the most important skills managers must acquire as change agents are the ability:

- To communicate effectively to colleagues and subordinates a need or changes in project goals and in individual tasks and responsibilities

- To sell plans and ideas to others, by creating a desirable and challenging vision of the future.

Change efforts today are guided and shaped by lessons learned over the past 30 years of trial and error in planned organisation change. Judging from the practices in most organisations today, three lessons in particular have been learnt:

- Participation is important

- According to Jamieson (1999), effective communication is related to participation. This is echoed by Kitchen (1997:18) when he states that "employees can only work effectively if they can participate in the organisation and they can only participate if they are fully informed"

- Teams generally perform better than individuals

- Process (how something is done) affects outcome (what is accomplished) (Dooley, 1998).

Various combinations of these lessons learned have greatly influenced the entire spectrum of change methodologies, from quality circles to Total Quality Management (TQM), from work redesign to reengineering, from task forces to large system change. With the increased use of groups in communication, there has been an exponential growth in the need for facilitation help. Thus more and more people from all organisational levels and functions, as well as numerous external resources, are now in, or need to be in, facilitator roles.

This study was conducted in a large listed organisation that has many projects running at any one time.

As a change manager assisting project managers on projects, a lot of frustration arising as a result of the limitations of the current tools available to assist the project managers in their role as communicators and facilitators, were observed.
The importance of tools to assist the project manager is highlighted by Harding (1998). Given the importance of change communication and the big role facilitation plays in change communication, it would be a natural assumption to make, that a tool that would address them all would be of great help for project managers. Furthermore, a tool that would be able to bridge the gap between the current tools available, would add a lot of value in the business.

A number of solution providers were contacted and, after consultation, it was decided that the business would evaluate MindManager X5 Pro as a solution. The rationale behind choosing MindManager X5 Pro was the fact that, on face value, the solution contains the necessary elements that would satisfy the business requirements.

Mindjet, the creators of MindManager $\times 5$ Pro define it as follows: "MindManager ${ }^{\circledR}$, Mindjet's visual tool for brainstorming and planning, offers business professionals a more effective way to electronically capture, organize, and communicate information and ideas.

As the digital alternative to note-pads, flipcharts and white boards, MindManager increases productivity through faster understanding, better decisions and reduced meeting time. XML-based MindManager seamlessly integrates with Microsoft ${ }^{\circledR}$ Office ${ }^{\circledR}$ and Enterprise data sets to harness corporate knowledge." (www.mindjet.com)

To evaluate the solution it is important to look at the claims made by the developers. The business specific culture and requirements must also be taken into account when evaluating the solution. The next section will address these two issues.

Claims made by developers

In order to evaluate MindManager $\times 5$ Pro, it is important to examine claims made by the developers. The developers claim that the software saves time and provides demonstrable return on investments. In addition to time-savings from the electronic capture of information, MindManager's developers claim improvement in, visual format facilitates communication, group consensus and decision-making in much shorter periods of time.

This is the result of:

- Faster decision-making

- Improved collaboration

- Increased success rates and accelerated projects

- Less time spent on preparation 
- Less time spent in meetings

- Increased team productivity.

In addition to the above-mentioned benefits, the developers also claim that the solution software:

- Has time-savings and productivity benefits

- Increases the number of new ideas generated during brainstorming by at least $20 \%$

- Increases project success rates by at least $20 \%$

- Reduces time spent transcribing and distributing notes by at least $30 \%$

- Moves projects from brainstorming and planning phases into implementation $20 \%$ faster

- Enables groups to reach consensus, make group decisions $20 \%$ faster

- Reduces time spent preparing for meetings by $20 \%$

- Enables groups/individuals to understand concepts $30 \%$ faster

The above-mentioned benefits of MindManager $\times 5$ Pro will be taken into consideration in evaluating the software. It is also important to take into account that, given the business specific culture and context, it will be necessary to evaluate the software against the best practices of the given business requirements. The business requires a solution that will assist project managers in their role as communicators, facilitators and project managers.

MindManager $\times 5$ Pro will be evaluated against the following best practice criteria in the related fields mentioned:

The research will establish how effective the tool would be in the specific business environment. As background to the study, it is necessary to look at relevant aspects of change communication, facilitation and project management.

\section{LITERATURE REVIEW}

Change communication, the role of facilitation, project management and mind mapping will be discussed below as background to the evaluation of MindManager X5 Pro against best practices in the different focus areas.

\section{Change communication}

Any organisation implementing new technology must consider the organisational and human resource issues associated with an implementation. Whether implementing specific components or wall-to-wall functionality, it is certain that a project will result in changes to some or all processes. This will potentially change job roles, responsibility, departmental boundaries, and organisational structure. Any initiative, which requires or brings about change, carries with it a risk that the change will not be accepted by the organisation (for a variety of reasons) and as a result will prevent full realisation of the planned benefits.

According to Clarke (1994) change can only be sustainable and irreversible when it is rooted in effective communication. Numerous scholars echo this:

- "Communication is key to a successful implementation" (Klein, 1996:32)

- Project failure is directly linked to the lack in communications (Collyer, 2000)

- "Project management, change management and communication go hand in hand" (Moore, 1998:22)

- "...communication is a key issue with regard to how successful change management programmes are implemented..." (Kitchen and Daly, 2002:53)

- Douglas (2003) emphasises the critical importance of change communication.

If MindManager $\times 5$ Pro were able to assist in the effectiveness of the communication, the solution would play a critical role in the change process, which would be a great asset to the business.
Role of facilitation in change communication

Attempts to "do" change to an organisation are unlikely to be successful because they do not take account of the diversity of individual responses to change nor do they respect the cognitive and personality attributes of the individual. Individuals and groups must be enabled to make change happen for them. As a facilitator of change, one needs to move away from providing solutions for people towards helping them develop solutions for themselves.

\section{Project management}

Project management is the process of managing, allocating and timing resources in order to achieve a given objective in an expedient manner. Alternately, project management could be defined as the process of achieving objectives by using the combined capabilities of project resources or assets (Badira \& Whitehouse, 1989).

Project management and communication are seen as key success factors underlying the change process (Jay \& Smith, 1996). Ahituv \& Neumann (1990) see project management as one of the major factors contributing to the success of information systems development and implementation.

The objective of any project is to produce an end result or product. This is achieved by means of resources and activities. The activities have definite starting points and end points. In short, a project produces unique end products by undertaking activities using resources within a period with a definite starting date and completion date. Projects are generally unique and will usually result in a change in the environment in which the project operates. The objective of project management is to ensure the success of a project by delivering a quality end product on time and within budget. This can be achieved by managing the following (Harding, 1998):

- Activities

- Resources

- Time and effort

- Intermediate products.

The organisation should provide tools to ensure productivity of project managers. A scheduling tool is a minimum. Risk analysis and process management tools should also be considered (Harding 1998).

Currently the Business, a large listed organisation, uses the following tools to assist project managers:

\section{- Microsoft Project}

As project manager, one has to keep track of numerous details, while always having an eye on the ultimate project goal. Microsoft Project benefits include:

- the program stores details about the project in its database

- the program assists the project manager in using the stored project information to calculate and maintain the project's schedule and costs, thereby creating the project plan

- the program keeps the information entered and the information it calculates in fields, which contain specific types of information, such as task names or durations.

Like a spreadsheet, Microsoft Project displays results of its calculations immediately. After entering all task information, one can immediately see the targeted task, start and finish, resource requirements, and project end date.

b) ARIS

ARIS (Architecture of Integrated Information Systems) combines a high-level business-oriented view with layers to address document workflow, software engineering, activitybased costing, and project management. Starting with a topdown business problem-definition stage, users can build views of their business in terms of organisation, data or resources, process control, and function or organisation. (http://www.moonglow.com/ARIS/ids01.html) 
c) Microsoft PowerPoint

PowerPoint is a high-powered software tool used for presenting information in a dynamic slide show format. Text, charts, graphs, sound effects and videos are just some of the elements PowerPoint can incorporate into your presentations with ease, whether it's for project kick-off meetings, project meetings or information sessions.

(http://www.actden.com/pp/guide.htm)

\section{d) Microsoft Outlook}

Outlook is Microsoft's mail client that includes tools to handle appointments, events, contacts, tasks and notes. With Outlook one can keep track of everything on one's calendar. Microsoft Outlook is a full-featured mail client that has menus, toolbars and help for sending and receiving mail, mail attachments, printing and forwarding mail, sorting and viewing the inbox, creating and managing mail folders, appointments, events, calendar views, meetings and meeting requests, contacts, tasks, journal entries, and notes. (http://www.bluestarcorp.com/what_is_outlook.cfm)

Integration between the applications creates a lot of additional work for the Business. This is why the Business is looking for a single application that could integrate the above-mentioned applications. The idea is not to replace the above-mentioned packages, but rather to acquire a solution that would enhance them.

The next section sets apart how the researcher went about executing the research. This section deals with the research design, participants/location of data, the data collection process and how data will be analysed.

\section{RESEARCH DESIGN}

The research design was conducted in two broad phases, namely the exploratory phase and the descriptive-empirical phase. A literature study provides background on all related theories and information that are relevant to the study in question. Aspects relating to change communication, facilitation, project management, mind mapping and theories relevant to this study were investigated.

TABLE 1

BEST PRACTICE CRITERIA COMMUNICATION

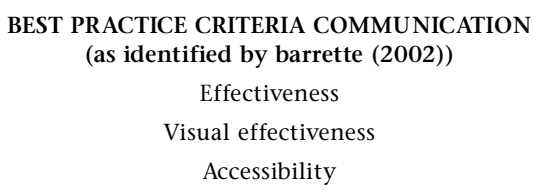

BEST PRACTICE CRITERIA FACILITATION

(as identified by Kaner (1996))

Information gathering

Structuring/clarification Participation

Meeting management

Data capturing

BEST PRACTICE CRITERIA PROJECT MANAGEMENT

(as identified by Loo (2003))

Scheduling

Integration

Knowledge management

Meeting management

Tracking issues

Evaluation/monitoring

Documentation

Planning

Reporting

Tasks management

\author{
MINDMANAGER CLAIMS \\ (www.mindjet.com) \\ Enhances decision making process \\ Saves time (accelerates project implementation) \\ Improves collaboration \\ Ensures clarity (improves communication) \\ Boosts team productivity
}

\section{Participants/location of data}

Eight system implementation projects were part of the evaluation. Four project teams were using MindManager X5 Pro and four project teams were not using it. The project team size varied between 8 and 80 and the stakeholders involved varied between 178 and 2500. The project managers, end-users and team members were involved in the evaluation of Mindmanager $5 \times$ Pro against the best practice criteria regarding use and added value in project management and facilitation. Table 2 sets out participants and project data that are using MindManager $\times 5$ Pro. Table 3 sets out participants and project data that not using MindManager $\times 5$ Pro.

TABLE 2

Participants and project data - using mindmanager X5 Pro

\begin{tabular}{|c|c|c|}
\hline Project & $\begin{array}{l}\text { Team } \\
\text { members }\end{array}$ & End-users \\
\hline $\begin{array}{l}\text { Project A - Quality maintenance system } \\
\text { implementation (Site 1) }\end{array}$ & 30 & 500 \\
\hline $\begin{array}{l}\text { Project B - Quality maintenance system } \\
\text { implementation (Site 2) }\end{array}$ & 10 & 178 \\
\hline $\begin{array}{l}\text { Project C - ERP implementation (Specific modules } \\
\text { of the solution were implemented) }\end{array}$ & 80 & 2500 \\
\hline Project D - Roles and re-engineering project & 8 & 2500 \\
\hline
\end{tabular}

TABLE 3

PARTICIPANTS AND PROJECT DATA - NOT USING Mindmanager X5 Pro

\begin{tabular}{lcc}
\hline Project & $\begin{array}{c}\text { Team } \\
\text { members }\end{array}$ & End-users \\
\hline $\begin{array}{l}\text { Project E - Quality maintenance system } \\
\text { implementation (Site 3) }\end{array}$ & 15 & 120 \\
$\begin{array}{l}\text { Project F - Quality maintenance system } \\
\text { implementation (Site 4) }\end{array}$ & 10 & 103 \\
$\begin{array}{l}\text { Project G - ERP implementation (The modules } \\
\text { in this implementation differ from modules } \\
\text { implemented in project C) } \\
\begin{array}{l}\text { Project H - EPM implementation } \\
\hline\end{array}\end{array}$ & 80 & 2500 \\
\hline
\end{tabular}

\section{Data collection}

A qualitative and quantitative approach was used to evaluate the use of Mindmanager $\times 5$ Pro as a communication, facilitation and project management tool in information technology related implementations. Mindmanager $\times 5$ Pro contribution to the outcome of the change process was also evaluated.

A series of semi-structured interviews using openended questions were conducted on-site with all 8 project managers (Appendix A). Interview transcripts were forwarded to all project managers for comments. All project managers also completed an anonymous online questionnaire (Appendix B).

A series of small group feedback sessions were conducted with project teams also using open-ended questions and an anonymous online questionnaire to evaluate effectiveness of the tool. Table 4 refers to actual involvement of 
project teams and the feedback received. Table 5 shows participant feedback received from those not using MindManager X5 Pro.

TABLE 4

ACtual Participants - team using Mindmanager X5 Pro

\begin{tabular}{lcc}
\hline Project & Team members & Feedback received \\
\hline $\begin{array}{l}\text { Project A - Quality maintenance } \\
\text { system implementation }\end{array}$ & 30 & 15 \\
$\begin{array}{l}\text { Project B - Quality maintenance } \\
\text { system implementation }\end{array}$ & 10 & 5 \\
$\begin{array}{l}\text { Project C - ERP implementation } \\
\begin{array}{l}\text { Project D - Roles and re-engineering } \\
\text { project }\end{array}\end{array}$ & 80 & 18 \\
\hline
\end{tabular}

TABLE 5

ACtual PaRticipants - Not USIng Mindmanager X5 Pro

\begin{tabular}{lcc}
\hline Project & Team members & Feedback received \\
\hline $\begin{array}{l}\text { Project D - Quality maintenance } \\
\text { system implementation }\end{array}$ & 15 & 10 \\
$\begin{array}{l}\text { Project E - Quality maintenance } \\
\text { system implementation }\end{array}$ & 10 & 4 \\
Project F - ERP implementation & 80 & 15 \\
Project G - EPM implementation & 8 & 3 \\
\hline
\end{tabular}

Evaluation could be defined as the "process for gathering information to assess the worth of an event or process" (Oliver, 1998:23). Different evaluation methods are available, but for the purpose of this study the summative evaluation method was chosen. According to Bhola (1990) and Gay \& Diehl (1992) summative evaluation takes place at or after completion of a process and is aimed at a comprehensive evaluation of a product or result. The product in this case is MindManager X5 Pro, used by project managers over a period of 3 months.

Statistical analysis/analysis of data

Quantitative and qualitative data was collected and interpreted. Results were documented and analysed. This study follows an exploratory data analysis, which looks at presenting frequencies, measuring location, and measuring dispersion (Collis, 2003). The main challenge to qualitative data analysis is that there is no clear and accepted set of conventions for analysis corresponding to those observed with quantitative data (Collis, 2003). Bromley (1986) suggests a quasi-judicial method for analysing qualitative data. The approach is concerned with the nature, source and quality of the evidence and the argument it supports.

\section{RESULTS}

The following six point lickert scale was used to rate the questionnaire.

Table seven is a comparison between the responses of project managers using the solution (4 participants) and project managers who did not use the solution (4 non-participants). Index results were added together and divided by the number of participants. Table 7 shows a comparison between participants perception regarding project management on their project.

Table 8 shows a comparison between participants perception regarding communication on their specific project.

Table 9 shows a comparison between participants perception regarding facilitation on their specific project.
Table 10 is a comparison between the responses of project team members that experienced the solution (participants) and project teams who did not experience the solution (nonparticipants) relative to communication. Only the questions relating to communication and facilitation were directed at the project teams.

Table 11 is a comparison between participants that experienced the solution and those who did not experience the solution in relation to facilitation.

\begin{tabular}{llllll} 
& \multicolumn{5}{c}{ TABLE 6 } \\
INDEX & & \\
\hline $\begin{array}{l}\text { Does not } \\
\text { meet } \\
\text { require- } \\
\text { ments }\end{array}$ & $\begin{array}{l}\text { Partially } \\
\text { meets } \\
\text { require- } \\
\text { ments }\end{array}$ & $\begin{array}{l}\text { Meets } \\
\text { require- } \\
\text { ments }\end{array}$ & $\begin{array}{l}\text { Exceeds } \\
\text { require- } \\
\text { ments on } \\
\text { a few } \\
\text { occasions }\end{array}$ & $\begin{array}{l}\text { Exceeds } \\
\text { require- } \\
\text { ments } \\
\text { mostly }\end{array}$ & $\begin{array}{l}\text { Exceeds } \\
\text { require- } \\
\text { ments } \\
\text { consistently }\end{array}$ \\
\hline 1 & 2 & 3 & 4 & 5 & 6 \\
\hline
\end{tabular}

TABLE 7

Project management

\begin{tabular}{lcc}
\hline & $\begin{array}{c}\text { Project managers } \\
\text { using MindManager } \\
\text { X5 Pro }\end{array}$ & $\begin{array}{c}\text { Project managers } \\
\text { not using } \\
\text { MindManager X5 Pro }\end{array}$ \\
\hline Scheduling & 4.2 & 4 \\
Integration between applications & 6 & 4 \\
Knowledge management & 4,9 & 3 \\
Meeting management & 6 & 2 \\
Tracking of issues & 4,2 & 3 \\
Evaluation/monitoring & 5 & 4 \\
Documentation & 3,25 & 3 \\
Planning & 6 & 3,25 \\
Reporting & 4,8 & 3 \\
Task management & 6 & 3 \\
\hline
\end{tabular}

TABLE 8

Communication

\begin{tabular}{lcc}
\hline & $\begin{array}{c}\text { Project managers } \\
\text { using MindManager } \\
\text { X5 Pro }\end{array}$ & $\begin{array}{c}\text { Project managers } \\
\text { not using } \\
\text { MindManager X5 Pro }\end{array}$ \\
\hline Communicates clearly and effectively & 5 & 2,25 \\
Presents concepts effectively & 6 & 3 \\
Easy to understand & 5 & 3 \\
Easy to access information & 5 & 2,25 \\
\hline
\end{tabular}

TABLE 9

FaCilitation

\begin{tabular}{lcc}
\hline & $\begin{array}{c}\text { Project managers } \\
\text { using MindManager } \\
\text { X5 Pro }\end{array}$ & $\begin{array}{c}\text { Project managers } \\
\text { not using } \\
\text { MindManager X5 Pro }\end{array}$ \\
\hline Information gathering & 6 & 3 \\
Structuring ideas and clarification & 6 & 2 \\
Participation & 6 & 2,25 \\
Meeting management & 6 & 3,25 \\
Data capturing & 6 & 3 \\
\hline
\end{tabular}


TABLE 10

TEAMS EXPERIENCE - COMMUNICATION

\begin{tabular}{lcc}
\hline & $\begin{array}{c}\text { Project managers } \\
\text { using MindManager } \\
\text { X5 Pro }\end{array}$ & $\begin{array}{c}\text { Project managers } \\
\text { not using } \\
\text { MindManager X5 Pro }\end{array}$ \\
\hline $\begin{array}{l}\text { Communicates clearly and } \\
\text { effectively }\end{array}$ & 5,25 & 3,25 \\
Presents concepts effectively & 5,75 & 3,5 \\
Easy to understand & 5,25 & 3 \\
Easy to access information & 4,75 & 2,25 \\
\hline
\end{tabular}

TABLE 11

TEAM EXPERIENCE - FACILITATION

\begin{tabular}{lcc}
\hline & $\begin{array}{c}\text { Project managers } \\
\text { using MindManager } \\
\text { X5 Pro }\end{array}$ & $\begin{array}{c}\text { Project managers } \\
\text { not using } \\
\text { MindManager X5 Pro }\end{array}$ \\
\hline Information gathering & 5 & 3 \\
Structuring ideas and clarification & 5,5 & 3 \\
Participation & 5,8 & 2,25 \\
Meeting management & 4,8 & 2,8 \\
Data capturing & 5,5 & 3,25 \\
\hline
\end{tabular}
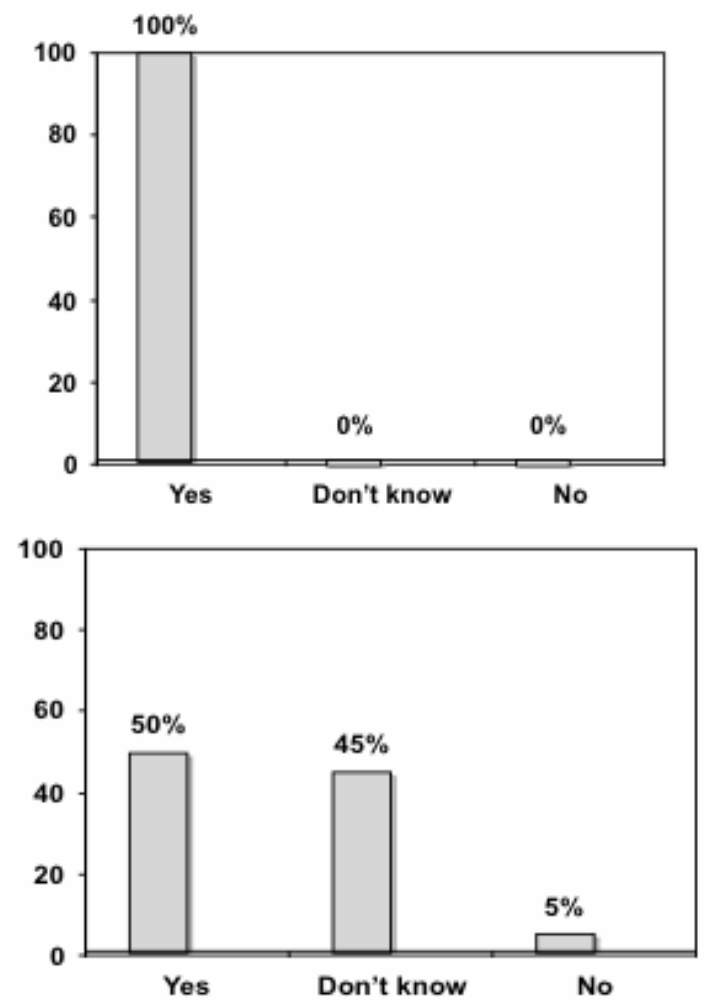

Figure 1: Did Mindmanager X5 Pro Add Any Value As A Project Management Tool?

The following table is a comparison between the project manager's perception of the claims made by the developer of the solution and those of the project team members.
Open-ended questions were directed at project managers and project team members who were using the tool. Their responses are captured in the following figures. Figure 1 refers to the value added by the tool in the field of project management.

TABLE 12

Perceptions

\begin{tabular}{lcc}
\hline & Project management & Project teams \\
\hline Enhanced decision making process & 5,25 & 4 \\
$\begin{array}{l}\text { Saved Time (accelerated project } \\
\text { implementation) }\end{array}$ & 3 & 3,25 \\
$\begin{array}{l}\text { Improved collaboration } \\
\text { Insured clarity (Improved }\end{array}$ & 4,85 & 4,25 \\
communication) & 5,25 & 4,15 \\
Boost team productivity & 4,7 & 4,9 \\
\hline
\end{tabular}

Both groups had the opportunity to provide reasons for their responses. This is captured in table 13 and 14 . Table 13 sets out the reasons given by project managers

TABLE 13

REASONS GIVEN FOR RESPONSES BY PROJECT MANAGERS

\begin{tabular}{lcc}
\hline Yes & Don't know & No \\
\hline Help keep project on track & None & None \\
Reduced time of project implementation & & \\
Support in development of action plan & \\
Tool to manage documentation & \\
Helped in identifying inefficiencies & \\
Enhanced time management & \\
Made information management much easier & \\
Link between planning and Microsoft Project & \\
Meeting management improved
\end{tabular}

TABLE 14

REASONS GIVEN FOR RESPONSES BY PROJECT TEAM MEBERS

\begin{tabular}{|c|c|c|}
\hline Yes & Don't know & No \\
\hline $\begin{array}{l}\text { Increase in personal and team } \\
\text { productivity } \\
\text { Effective resource management } \\
\text { Increase collaboration among } \\
\text { global offices } \\
\text { Improved information management } \\
\text { Improved team morale }\end{array}$ & $\begin{array}{l}\text { Did not } \\
\text { experience project } \\
\text { management } \\
\text { qualities of the } \\
\text { tool (in group } \\
\text { discussion } 45 \% \\
\text { indicated that } \\
\text { they did not } \\
\text { experience it) }\end{array}$ & $\begin{array}{l}\text { Think that the } \\
\text { tool takes up a } \\
\text { lot of time }\end{array}$ \\
\hline
\end{tabular}

Table 14 sets out the reasons provided by project team members.

Figure 2 refers to responses of project managers and team members regarding the value added by tool in relation to facilitation.

Both groups had the opportunity to provide reasons for their responses. This is captured in table 15 and 16. Table 15 shows reasons given by project managers. 

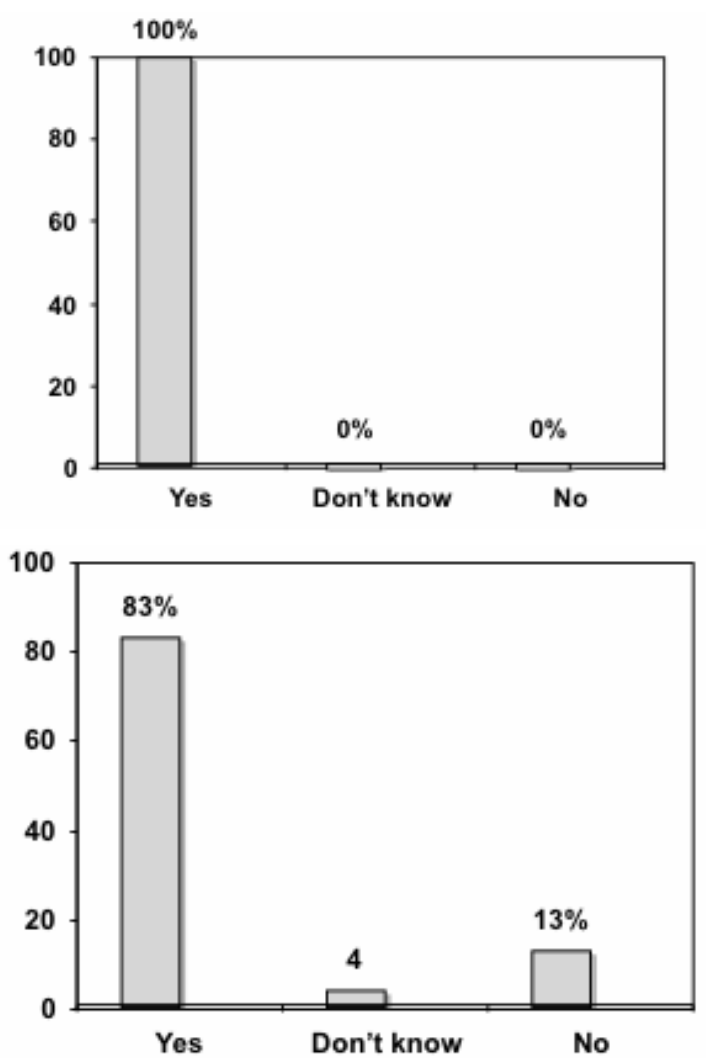

Figure 2: Did Mindmanager X5 Pro Add Any Value As A Facilitation Tool?

Figure 3 refers to responses of project managers and team members regarding the value added by the tool in relation to communication.
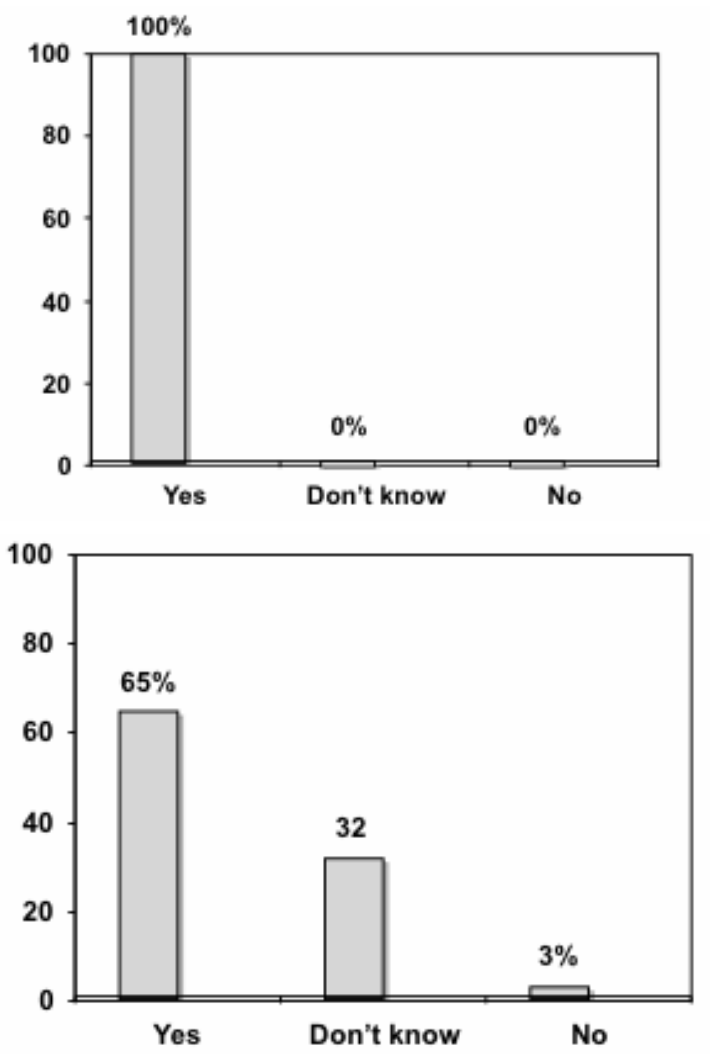

Figure 3: Did Mindmanager X5 Pro Add Any Value As A Communication Tool?
Both groups had received the opportunity to provide reasons for their responses. This is captured in table 17 and 18 . Table 17 shows the project manager's reasons.

TABLE 15

REASONS GIVEN FOR RESPONSES BY PROJECT MANAGERS

\begin{tabular}{lcc}
\hline Yes & Don't know & No \\
\hline $\begin{array}{l}\text { Improved brainstorming and capturing of data } \\
\text { Capture and documentation of information }\end{array}$ & None & None \\
$\begin{array}{l}\text { Increased participation and excitement around } \\
\text { process improvement, and made meetings }\end{array}$ & \\
highly productive· Improved problem solving & \\
Keep track of multiple project details & \\
Reporting made easier & \\
Increase in personal and team productivity & \\
\end{tabular}

TABLE 16

REASONS GIVEN FOR RESPONSES BY PROJECT TEAM MEMBERS

\begin{tabular}{|c|c|c|}
\hline Yes & Don't know & No \\
\hline $\begin{array}{l}\text { Increase group participation } \\
\text { Easy information capturing } \\
\text { Made meetings productive }\end{array}$ & $\begin{array}{l}\text { Did not } \\
\text { experience } \\
\text { facilitation } \\
\text { qualities of the } \\
\text { tool }\end{array}$ & $\begin{array}{l}\text { Just a another } \\
\text { gadget } \\
\text { Another tool to } \\
\text { get used to }\end{array}$ \\
\hline
\end{tabular}

TABLE 17

REASONS GIVEN FOR RESPONSES BY PROJECT MANAGERS

\begin{tabular}{lcc}
\hline Yes & Don't know & No \\
\hline $\begin{array}{l}\text { Reduced paper work Improved communication } \\
\text { Clarify and communicate project vision and strategy }\end{array}$ & None & \\
Improved internal project communication & & \\
Project team high-level communication improved & & \\
Improved ability to manage, communicate & \\
use of resources & \\
\hline
\end{tabular}

Table 18 sets out the reasons provided by the project team members.

TABLE 18

REASONS GIVEN FOR RESPONSES BY PROJECT TEAM MEMBERS

\begin{tabular}{lll}
\hline Yes & Don't know & No \\
\hline $\begin{array}{l}\text { Bridging language barriers } \\
\begin{array}{l}\text { Project team high-level } \\
\text { communication improved }\end{array}\end{array}$ & $\begin{array}{l}\text { Did not } \\
\text { experience } \\
\text { communication }\end{array}$ & $\begin{array}{l}\text { Have to get used } \\
\text { to new tool }\end{array}$ \\
$\begin{array}{l}\text { Conveying complex ideas in a very } \\
\text { simple, visually appealing format }\end{array}$ & $\begin{array}{l}\text { qualities of the } \\
\text { tool }\end{array}$ & \\
$\begin{array}{l}\text { Streamline communication } \\
\text { Ability to communicate complex } \\
\text { ideas in a understandable way } \\
\text { Concise and well organised }\end{array}$ & & \\
\hline
\end{tabular}

\section{DISCUSSION}

It is not difficult to see the benefits MindManager $\times 5$ Pro brought to the projects. We have to take in to consideration that there could have been other factors involved in the results, such as quality of project managers and teams, experience of project mangers and teams and the different project environments.

The overwhelming difference in perception between nonparticipants and participants indicates that MindManager $\times 5$ Pro 
definitely played a major role in the project management, communication and facilitation process.

According to project managers, major improvements took place in the following fields:

- Integration between applications

- Meeting management

- Task management

- Presentation of concepts

- Information management

- Participation

- Meeting management, and

- Data capturing.

All project managers indicated that the solution exceeded requirements in the above-mentioned fields. The only instance where participants and non-participants scored their current context almost the same, was relating to documentation. MindManagers $\times 5$ Pro does not focus on documentation and that reflects in the evaluation. All project managers indicated that the solution added value in the field of project management, communication and facilitation.

Project team members rated MindManager $\times 5$ Pro between "Exceed requirements mostly" and "Exceed requirements consistently" in almost all fields, except in "accessibility of information" and "meeting management". Only 50\% of project team members indicated that the solution adds value as a project management tool, mostly because team members could not answer for project managers. 83\% indicated that the solution adds value as a facilitation tool. $65 \%$ indicated that the tool adds value as a communication tool. This is mainly because of the fact that $32 \%$ did not experience the tool.

\section{Conclusion}

In conclusion I think it is fair to say that MindManager X5 Pro adds a lot of value for this specific project management environment. It is important to mention that the solution was evaluated in a specific business context and added value for them. One may not be able to assume that the solution would provide the same benefits in all environments would be to push the envelope.

\section{REFERENCES}

Ahituv, N. \& Neumann, N. (1990). Principles of information systems Management. Dubuque: Brown.

Badira, A.D. \& Whitehouse, G.E. (1989). Computer Tools, Models and Techniques for Project Management. New York: Blue Ridge Summit.

Barrette, D. (2002). Change communication: using strategic employee communication to facilitate major change. Corporate Communications: An International Journal, 7 (4), 219-231.

Bhola, H.S. (1990). Evaluating "Literacy for development" projects, programs and campaigns: Evaluation planning, design and implementation, and utilization of evaluation results. Hamburg: UNESCO Institute for Education.

Bromley, D.B. (1986). The Case Study Methodology in Psychology and Related Disciplines. Chichester: Wiley.

Buchanan, D \& Boddy, D. (1992). The Expertise of the Change Agent. New York: Prentice-Hall.

Clarke, L. (1994). The essence of Change. Hertfordshire: Prentice Hall International (UK) Ltd.

Collis, J. (2003). Business Research: A practical guide for undergraduate and postgraduate students. Hampshire: Palgrave Macmillan.

Collyer, M. (2000). Communication 0 the route to successful change management. Lessons from Guinness Integrated Business Program. Supply Chain Management: An International Journal. 5, (5), 222-225.

Dooley, J. (1998). A Whole-Person/Systemic Approach to Organization Change Management. Retrieved 2006 from the World Wide Web:http://www.well.com/user/dooley/ change.pdf

Douglas, C. \& Martin, J.S. \& Krapels, H.R. (2003). Change Communication. Association of Business Communication Convention.

Eitington, J. E. (1997). The winning manager: Leadership skills for greater innovation, quality, and employee commitment. Houston, TX: Gulf.

Gay, L.R. \& Diehl, P.L. (1992). Research methods for business and management. New York: Macmillan Publishing Company.

Harding, A.S. (1998). Change Management during the implementation of Information Systems. Unpublished masters dissertation, Johannesburg: Rand Afrikaanse Univeriteit (Short Dissertation: MCom).

http://www.actden.com/pp/guide.htm

http://www.bluestarcorp.com/what_is_outlook.cfm

http://www.mindjet.com

http://www.moonglow.com/ARIS/ids01.html

Jamieson, G.H. (1985). Communication and Persuasion. London: Routledge Kegan \& Paul.

Jay, K.E. \& Smith, D.C. (1996). A generic change model for the effective implementation of information systems. South African Journal of Business Management, 27: 65-69

Kaner, S. \& Lind, L. \& Toldi, C. \& Fisk, S. \& Berger, D. (1996) Facilitator's Guide to Participatory Decision-Making. Gabriola Island: New Society Publishers.

Kitchen, P. (1997). Public Relations: Principle and Practice, $1^{\text {st }}$ ed. Thomson Business Press, London.

Kitchen, P.J. \& Daly, F. (2002). Internal communication during change management. Corporate Communications. 7, (1), 46-53.

Klein, S.M. (1996). A management communication strategy for change. Journal of Organizational Change Management. 9, (2), $32-46$.

Loo, R. (2003). A multi-level casual model for best practices in project management. Benchmarking: An International Journal. $10,29-36$.

Moore, C. (1998). IT project manager stresses communication and learning. Infoworld, 20:79, March.

Oliver, M. 1998. A framework for evaluating the use of educational technology. Retrieved 2006 from the World Wide Web:http://www.unl.ac.uk/latid/elt/report1.htm 